\title{
A REPORT ON THE PENNSYLVANIA LOYALTY ACT
}

Clark Byse $\dagger$

Introduction of Senate Bill No. 27 on January 15, 1951, by Senator Albert R. Pechan began a bitter, prolonged, and widely publicized debate which culminated in enactment of the Pennsylvania Loyalty Act on December 22, 1951. ${ }^{1}$ Senator Pechan's original Bill contained only two sections and required every employee of the Commonwealth or of any of its political subdivisions to file a written statement under oath or affirmation that he was not a subversive person as defined in the Bill. By the time the Bill was finally enacted, it had been amended nine times, had grown to seventeen sections, and embraced a variety of topics in addition to the original requirement of a loyalty oath from public employees. ${ }^{2}$

Although the new provisions added in the amendment process drastically changed Senator Pechan's original proposal, the Bill was known throughout as the "Loyalty Oath Bill" and public discussion and debate generally took the form of support of or opposition to a loyalty oath. The emphasis on the oath aspects of the Bill, the numerous revisions and amendments as the measure passed through the legislative mill, and the omnibus character of the Act finally adopted militated against public knowledge and understanding of its terms. And in the interval since its adoption, although there have been sporadic reports concerning the effect of the Act, for all practical purposes the "Pechan Act" has moved off the front and editorial pages of the papers of the state.

Affecting, as it does, basic civil liberties, the Act is much too significant to be permitted to lapse into obscurity and thus to escape the public scrutiny it merits. This paper is an endeavor to rescue the legislation from its present oblivion by providing a report of the present

† B.E., 1935, Wisconsin State College; LL.B., 1938, University of Wisconsin; J.S.D., 1952, Columbia University; Professor of Law, University of Pennsylvania Law School.

1. Pa. Stat. Ans. tit. 65, $\$ 212-225$ (Purdon Supp. 1951). The effective date of the Act was March 1, 1952.

2. Said Senator Pechan late in December 1951: "I'm not too happy about the House version of my bill. I would have preferred it when it was four pages long, when it passed the Senate back in March, not the 34-page thing it has become now." Philadelphia Evening Bulletin, Dec. 21, 1951, p. 16, col. 7. 
status of the Act and its administration. The story will be told with a minimum of documentation and discussion of strictly legal issues, for the purpose of the paper is to provide a basis for informed public evaluation of the legislation rather than to enlighten the legal profession concerning the many legal questions presented by the Act.

The Pennsylvania Loyalty Act contains five major provisions: (1) Every employee of, and applicant for employment by, the Commonwealth of Pennsylvania or of any of its political subdivisions (including school districts) is required to swear to or affirm his loyalty. (2) A1though an oath is not required of persons holding state or local elective offices at the time the Act became effective, every person who thereafter becomes a candidate for "State, district, county, or local public office" is required to file with his nomination papers a statement under oath or affirmation that he is not a "subversive person" as defined in the Act. (3) Any employee of the Commonwealth or of any of its political subdivisions who, after due hearing, is determined to be a subversive person shall be discharged. (4) Any applicant for employment by the Commonwealth or any of its political subdivisions shall not be employed if he is a subversive person or if "on all the evidence there is reasonable doubt concerning his loyalty to the government of the United States or the Commonwealth of Pennsylvania." (5) No public funds shall be paid to any state-aided institution of learning unless the institution annually files with the Governor a written report setting forth what procedures the institution has adopted to determine whether it has reason to believe that any subversive persons are in its employ and what steps, if any, have been or are being taken to terminate such employment. The report also shall set forth unequivocally that the institution has no reason to believe that any subversive persons are in its employ.

\section{Employee and Applicant Loyalty Oath Requirement}

The statute prescribes the form of written statement to be made under oath or affirmation by all employees of, or applicants for employment by, the Commonwealth or of any of its political subdivisions:

"I,$\ldots \ldots \ldots \ldots \ldots \ldots$ do solemnly swear (or affirm) that I will support, obey and defend the Constitution of the United States and the Constitution of this Commonwealth, and that I will discharge the duties of..$\ldots \ldots \ldots \ldots$ with fidelity.

"And I do further swear (or affirm) that I do not advocate, nor am I knowingly a member of any organization that advocates, the overthrow of the government of the United States or of this Commonwealth by force or violence or other unconstitutional means, or seeking by force or violence to deny other persons their 
rights under the Constitution of the United States or of this Commonwealth.

"And I do further swear (or affirm) that I will not so advocate nor will I knowingly become a member of such organization during the period that I am an employee of the Commonwealth of Pennsylvania (or political subdivision thereof)."

The Act also provides that the written statement "shall contain notice that it is subject to the penalties of perjury." Any employee failing or refusing to execute the oath shall be discharged immediately; and any applicant who fails or refuses to do so shall not be employed.

The Act became effective on March 1, 1952. On or before that date thousands of state and local employees throughout the Commonwealth executed the required loyalty statement. Presumably, the statements have been appropriately filed by the various appointing authorities charged by the Act with the duty of requiring the oaths. ${ }^{3}$ To date there have been no perjury prosecutions. The only tangible results of the oath requirement have been: (a) a feeling of resentment on the part of many loyal teachers and employees who object to being singled out and forced to take an oath not required of other citizens; (b) the resignation of an employee of the Philadelphia City Planning Commission who, after executing the loyalty statement, resigned his position in protest against the requirement; and (c) the discharge of three teachers, a social worker, three doctors, and a nurse who refused to execute the required statement. ${ }^{4}$

Two of the discharged teachers and the social worker are members of the Religious Society of Friends. Their reasons for refusing to execute the required statements are set forth in the footnote. ${ }^{5}$ There was no suggestion by anyone that any of these individuals was in any

3. Section 2 defines "appointing authority" to mean "any person, department, board, commission or other agency of the Commonwealth, or of any political subdivision thereof, who appoints or employs officers or employees."

4. There may have been additional discharges for failure to sign the oath. If so, they are not reported in the files of Greater Philadelphia Branch of the American Civil Liberties Union, and have escaped the writer's attention.

5. Miss Helen $H$. Corson, social worker in the Department of Public Instruction, Commonwealth of Pennsylvania: "I am by conviction, a Christian pacifist and am therefore opposed to the use of violent means for the achievement of any end, no matter how righteous. Certainly not for the overthrow of our Government which I love and cherish. I could therefore with perfect truthfulness take this oath. My objection to the Oath is that I feel its effect will be to curb freedom of thought and expression: a curb which we expect in communist countries but which is directly contrary to the spirit and practice of Democracy. During the long legislative struggle over this Bill, many teachers have been afraid to voice their opposition to it for fear of being suspected of subversion. This forcibly illustrates to me the fact that the Bill is producing, among many, a timid conformity instead of the free thinking and discussion on which the stability and progress of our nation rests. . . for these reasons I cannot conscientiously support this Act. . . ."

Mr. Paul W. Goulding, high school teacher at Nazareth, Northampton County: "That the actual words of the Pennsylvania Loyalty Oath are relatively innocuous 
way subversive or disloyal. ${ }^{8}$ As was said of similar discharges occuring in Maryland under the Ober law, "Certainly the Quakers are as far removed from the class of dangerous revolutionaries as anyone could be." 7 These people lost their jobs not because they represented an actual or potential threat to democratic freedoms, but because, as their statements demonstrate, they are individuals of conscience who possessed the steadfastness to follow the dictates of conscience.

The discharged doctors-two interns and a junior resident physician-and the nurse were employed at the Philadelphia General Hospital. ${ }^{8}$ As in the case of the Quakers, there was not the slightest sug-

is a tribute to the resistance by a free people and their representatives against coercive forces that would cast our very thoughts in a mold of conformity, mechanization, and violence. In spirit, however, the Oath is one of several instruments by which we are being 'persuaded' that totalitarian regimentation must be met by totalitarian, 100 per cent 'Americanism'. In a day when the impulse to conform, to acquiesce, to go along, is the instrument used in subjecting men to dictatorial rule throughout the world, non-conformity - with a religious motivation-becomes a means of preserving the dignity of man. Although I am neither communist nor subversive, I must say ' $\mathrm{No}$ ' to the spirit of the Oath. Through the years Quakers have continuously declared loyalty of citizenship, but the superficial and unreal implication that we have only to close our minds to Communism in order to save America is false and dangerous."

Mr. Eugene L. Mercer, Jr., grade school teacher at Millville, Montour County: "The words of the oath are harmless but the principles behind the law are harmful, in my opinion. I have been very much tempted to keep my teaching job. . . . However, to me it is more important to withhold my support from this law. . . . This law helps create an atmosphere of mistrust amongst us, inhibits complete freedom of discussion. We must have this freedom if we are to boldly seek out a peaceful solution of the conflict with Communists. ... We know that the conditions that invite Communism are poverty and great economic and political injustices. The controls of this law will not help stop Communism or eliminate the conditions that create it . . . ."

The third teacher was Mr. Robert Repas, employed part-time by the School District of Philadelphia. Mr. Repas' statement of reasons for not taking the oath reads in part as follows: "I cannot accept the widespread doctrine which says a person employed in public service automatically becomes a second class citizen and loses certain civil liberties. In an age of growing hysteria, legislation like the Pechan Bill can result in closing the avenues of freedom which are so vital to the teaching profession... The criterion for a teacher is no longer professional competence but his or her professional and philosophical beliefs. Limitations upon the right to think and say are thought control methods contrary to a democratic society.... The intent behind this kind of legislation should also be taken into consideration. Individuals and organizations most apt to be supporting it in many cases have been leading opponents of any effort made by members of the teaching profession to examine critically our political and economic institutions. . . My refusal to sign the oath is based upon the fact that the Pechan Bill curtails civil liberties, contributes to hysteria and is useless for the purpose designed."

6. See, e.g., the Danville Morning News, April 1, 1952, p. 4, col. 6: "His [Mercer's] loyalty to the United States, and the possibility of his belonging to a subversive group, was not in question at any time. ..." Id. p. 1, col. 4: "Members of the board felt that he was an excellent teacher, but the law . . . left them with no choice but to dismiss him."

7. Prendergast, The Ober Anti-Communist Law in The States and Subversion 140, 166-167 (Gellhorn ed. 1952).

8. Dr. Julina Gylfe of Irwin, Ill., was the junior resident physician; the nurse was Mrs. John Fitzgerald, Jr., Philadelphia; and the interns were Drs. Anna Chirico, Jeanette, Pa., and Donald Wohlrabe, Philadelphia. (Four additional interns were discharged along with this group for refusing to execute the oath statement; 
gestion that any of these persons was in any way subversive. They, too, were discharged because they had the courage to remain true to their conscientious convictions. ${ }^{9}$ Only the nurse has appealed her discharge to the courts. The case is now pending in the Court of Common Pleas No. 6, Philadelphia County.

The demonstrable consequences of the oath requirement thus are resentment on the part of public employees and discharge of persons of unquestioned loyalty and competency. Legislation causing such harmful results perhaps could be justified if there were sound countervailing reasons for its enactment. But it is difficult to find a rational justification for the oath requirement. Certain it is that a forced loyalty oath does not contribute in any way to making public employees loyal. Loyalty can be earned but it cannot be coerced.

The argument most commonly advanced in favor of a loyalty oath is simply, "Why not?" Why should any loyal American object to swearing that he does not advocate the forcible overthrow of the government and that he is not and will not become a member of any organization so advocating? "But," as Alan Barth says," "a prior and more apposite question is "Why?" "10 Why should public employees "be singled out as a special class and be asked to profess their innocence of an attitude which there is no good reason to suspect them of holding?" 11 If we are to demand an expurgatory oath from public employees why not demand it of other groups in society? Why not require all bankers to swear that they are not embezzlers, lawyers that they are not ambulance-chasers, doctors that they are not abortionists, businessmen that they have not violated the anti-trust laws? "Imagine the indignation which these proposals would raise from men who see no harm" in public employees' oath laws; yet "these offenses are far more frequent in the respective occupations" than disloyalty among public employees, and "they are at least as injurious to society." 12

these four were later reinstated upon signing the oath.) Drs. Gylfe and Chirico objected to being "put under compulsion to do a vain thing." Dr. Wohlrabe quoted Benjamin Franklin's dictum that "the people who give up personal liberty for a little safety deserve neither liberty nor safety." Mrs. Fitzgerald felt that "the nation that is not watchful of its liberty will lose it. I believe also that the individual who will not stand for his rights will have no rights, and I believe the first duty of every American citizen is to protect himself and his country in all the liberties we have. If I were to condone the principle of the extorted loyalty oath $I$ would be a very poor citizen indeed. . . . I would rather. . . be dismissed from my employment as a servant of the sick. . .."

9. The Board of Trustees of the Hospital discharged the non-signers only after being advised by the City Solicitor that under the act it "had no choice" in the matter. The minutes of the meeting stated that the Board "expressed regret at having to dismiss those persons who failed to execute" the oath.

10. Barth, The Loyalty of Free Men 218 (Cardinal ed. 1952).

11. Ibid. at $\mathrm{xxxi}$.

12. Professor Zechariah Chafee's foreword to BARTH, op. cit. supra note 10, 
Another argument sometimes advanced in favor of the oath is that an oath should be required in order to convict a few Communists or other subversives of perjury: "If one person is convicted of perjury under this bill, that would be reason enough for its enactment." ${ }^{13}$ The reasoning seems to be that honest, loyal employees, having nothing to hide, will tell the truth; but a Communist or other subversive, fearing loss of employment, will commit perjury; he can then be punished by fine or imprisonment. ${ }^{14}$ This argument reflects a basic misconception of the purpose and function of perjury statutes. Perjury statutes do not exist in order to punish persons whose ideas or actions we do not like. On the contrary, the function of the sanction of punishment for perjury is to coerce individuals to give public officials information needed by the latter in the performance of their public duties. A person who wilfully lies about a material matter which a public official is lawfully investigating should be punished, because if he is not, the investigatory process would be frustrated. The perjury sanction is a means to an end, not an end in itself. Those who would enact legislation in order to induce perjury on the part of subversives confuse ends with means and pervert the legislative process.

A third possible explanation for the oath is that it is a method for identifying employees who advocate forcible overthrow of the government, or are members of an organization which they know advocates such overthrow, so that the employees may be discharged. A difficulty with this reason for the oath requirement is that it assumes that all employees who so advocate should be discharged. As will be developed later in this paper ${ }^{15}$ there are serious doubts whether this assumption is correct. This explanation also assumes that the oath is an effective device for ferreting out subversives. This, too, is an extremely dubious proposition. Experience under other loyalty oath laws demonstrates that few if any subversives have been uncovered by an oath requirement. ${ }^{16}$ Finally and perhaps most important, this reason for an oath

13. According to the writer's recollection, this statement or one very similar to it was made by a proponent of the Pechan Bill at the hearing before the House Committee on State Government, August 14, 1951, Harrisburg, Pa.

14. Punishment for perjury involves a fine not exceeding $\$ 3000$ or imprisonment not exceeding seven years, or both; a person convicted of perjury is "forever disqualified from being a witness in any matter in controversy." PA. STAT. ANN. tit. 18, $\$ 4322$ (Purdon 1945).

15. See, infra pp. 10-11.

16. Gelimorn, The States and Subversion 367-368 (1952): "What high hopes attend the enactment of loyalty oath laws! What comfort there is in believing that at last the ranks of public employees and educators will be purified! Yet, once the laws are changed, the old doubts survive. Communist infiltration is still possible, for the really dangerous 'Reds,' the unidentified plotters, are unlikely to stickle at taking the oaths required of them. Of course, a few people always balk, but they seem to be the wrong people. After some years of operation, the loyalty oath required of Detroit's municipal employees had claimed a single casualty- 
fails to take into account the affirmative harm worked by an oath measure. Not only are people of conscience discharged and other employees made resentful, but the oath requirement undoubtedly discourages some highly qualified and dedicated persons from seeking public employment, thus contributing to a lowering of standards in teaching and other government employment.

The basic shortcomings of an oath requirement thus are: (1) it is not an effective means for accomplishing its objective of uprooting Communists and other subversives from public employment; (2) it deprives the public of the services of able persons of conscience who are unwilling to take the oath; (3) it causes understandable resentment on the part of those who are singled out to swear to their loyalty, for they not only object to the unwarranted suspicion of their loyalty but also oppose being pushed around; and (4) in questioning the loyalty of a sizeable group of citizens, it creates an atmosphere of suspicion which is neither healthy nor traditional in democratic societies. Unfortunately, experience under the act has served to confirm the appraisal of $\mathrm{Mr}$. George Wharton Pepper, former United States Senator and dean of the Philadelphia Bar:

"If Senate Bill 27 becomes law, two consequences are rertain to follow. One is that every communist to whom the statute is intended to apply will unhesitatingly take the prescribed oath and proceed with his subversive activities just as before. The other consequence is that people who, like me, are devoted heart and soul to our American constitutional system and who therefore value the freedoms which communism would destroy, will for that very reason refuse to take the oath lest its vague provisions be so construed as to limit their own liberty to think and act as free American citizens.

"Thus the statute will not injuriously affect those at whom it is aimed and will inevitably affect a substantial number of loyal and useful American citizens. Any statute which insures such results stands self-condemned both as unwise legislation and as a serious menace to constitutional liberty." 17

\section{Oath Reguired of Candidates for Elective Office}

Section 14 of the Act provides that no person shall become a candidate for any "State, district, county, or local public office" unless he shall file with his nomination papers a statement under oath or

a member of the sect of Jehovah's Witnesses. The first effect of the Ober Act in Maryland was to snare three Quakers whose religious rather than political dogmas prevented their conscientious compliance with the statute. In California a number of academics lost their appointments because they were unwilling to assert their innocence of communism, even though nobody so much as hinted that they were in fact guilty. In short, the bag has been a disappointing one."

17. Statement released August 14, 1951, by Earl G. Harrison, Esq., for the Greater Philadelphia Branch, American Civil Liberties Union. 
affirmation that he is not a subversive person as defined in the Act. ${ }^{18}$ In event of failure to file the statement, the candidate's nomination papers will not be filed by the election officials and his name will not be printed on the ballot. Ten candidates of minor political parties were refused the right to appear on the ballot in the 1952 election because of failure to file the required oath. ${ }^{19}$

Barring candidates for public office from a place on the ballot because of their beliefs or associations strikes hard at the foundations of free government. Democratic, representative government is based on the idea that the electorate shall exercise a choice among competing candidates and programs. Misguided voters who wish to vote for a candidate whose views are obnoxious to the majority should not be deprived of that opportunity merely because the majority of the citizenry disagrees with their judgment.

Communists and like-minded persons should be permitted to appear on the ballot because by allowing them to run for office we are able to gauge their appeal to the electorate. This will have "the salutary effect of refuting Communists' claims and quieting anti-Communists' fears that the party has a powerful following. The returns in the ballot box will only disclose how few the Communists among us are." 20 Moreover, we should not deny the Communists a place on the ballot, because denying them that right provides support for the basic Communist argument that their objective cannot be accomplished by peaceful means and that only violence and bloodshed can produce the change they seek. If violence is to be discouraged, peaceful avenues must be kept open.

18. Section 2 defines a "subversive person" as "any person who commits, attempts to commit or aids in the commission, or advocates, abets, advises or teaches by any means, any person to commit, attempt to commit, or aid in the commission of any act intended to overthrow, destroy, alter, or to assist in the overthrow, destruction or alteration of the constitutional form of government of the United States or of the Commonwealth of Pennsylvania, or any political subdivision of either of them, by force or violence, or who is knowingly a member of a subversive organization... as defined in this act."

"Subversive organization" is defined as "any organization which engages in or advocates, abets, advises or teaches, or a purpose of which is to engage in or advocate, abet, advise or teach, activities intended to overthrow, destroy or alter, or to assist in the overthrow, destruction or alteration of, the constitutional form of the government of the United States or of the Commonwealth of Pennsylvania, or of any political subdivison of either of them, by force or violence."

19. Letter from the Secretary of the Commonwealth, Gene D. Smith, dated November 21, 1952. The parties, names of the candidates and the Commonwealth office to which they aspired are as follows: Industrial Government Party-Paul H. Barnes (Auditor General), Thomas Grady (State Treasurer); Militant Workers Party-Clyde Turner (State Treasurer); Prohibition Party-Frances I. Miller (Auditor General), Adriel I. Peters (State Treasurer), Charles Palmer (Judge of Supreme Court), Joseph Sproule (House of Representatives), Clarence J. Shupp (House of Representatives); Independent Citizens Committee Party-Henry A. Nicholson (House of Representatives), Ethel L. Harting (House of Representatives).

20. Prendergast, supra note 7 , at 178 . 
Like the oath for public employees, the candidates' oath has an unwholesome deterrent effect in that persons of unquestioned loyalty and ability will not seek elective office because of the degrading oath requirement. ${ }^{21}$

Attacking the Communist problem by barring Communists from the ballot appears to be the result of an emotional reaction in a time of international tension. We dislike the Communists and we feel that we just have to do something. So we bar them from the ballot. But impairing the freedom of elections does not contribute to the solution of the Communist question. On the contrary, discriminatory action of that character will only aggravate the problem.

It might be argued that anyone running for elective office in a democracy should declare himself concerning the basic issue of forcible overthrow of the government. It could be urged that the voter should have unequivocal information concerning the candidate's stand on this fundamental question so that he could vote intelligently. Once there has been disclosure, the voter would cast his vote as he saw fit. This is not to advocate a disclosure requirement. It is simply to note that there is some sense in the disclosure idea. As much cannot be said of barring candidates from the ballot because of their beliefs or associations.

\section{Discharge of Subversive Employees}

Any appointing authority ${ }^{22}$ may, "upon written complaint," investigate any person employed (or appointed) by the authority to determine whether he is a subversive person. If upon such investigation, "it appears that such person is a subversive person," he is to be notified by the appointing authority. If an employee so notified fails to request a hearing within thirty days, he "shall immediately be discharged by the appointing authority." If the employee requests a hearing, the hearing is to be held by the appointing authority, which shall determine by "a fair preponderance of the evidence" whether the employee is a subversive person. If it is found that he is a subversive person, he is to be discharged. Final determinations of discharge by appointing authorities may be appealed to the Superintendent of Public Instruction in cases involving teachers and other persons employed in the public school system, and to the Civil Service Commission in cases involving public employees who are not employed in the public school system. The Superintendent and the Commissioner are empowered to affirm or reverse the appointing authority's determination and, in the

21. The writer has personal knowledge of one such instance. There undoubtedly are others.

22. "Appointing authority" is defined supra note 3. 
event of reversal, to order reinstatement of the employee, who shall be entitled to back pay from the date of his discharge. Unlike proceedings before most administrative agencies, proceedings under the Act are governed by "the rules of evidence . . . prevailing in the courts." Reasonable examination and cross-examination and the right to subpoena witnesses and to be represented by counsel are specifically guaranteed.

Decisions by the Superintendent of Public Instruction and by the Civil Service Commission may be appealed by the employee or the appointing authority to the court of common pleas of the county in which the appointing authority is located. If the employee aggrieved shall request it, the court hearing shall be de novo. The court is to "make whatever order it considers just, either affirming or reversing the action of the Civil Service Commission or the Superintendent of Public Instruction, and stating plainly whether the employee is to be discharged."

So far as is known, there have been no cases under the discharge provisions of the Act. If any does arise, the employee is assured of a "due hearing," representation by counsel, availability of subpoenas, application of court rules of evidence, right to cross-examine, a decision on the basis of the preponderance of the evidence, opportunity to appeal to the Superintendent of Public Instruction or the Civil Service Commission, and, if requested, a de novo court review in which the court shall make whatever order it considers "just." Whatever one may think of the legislative judgment that "subversive" persons are to be discharged from public employment, there can be no doubt that this impressive array of safeguards amply protects the accused employee's procedural rights. It is perhaps worth noting in passing that most of these protections were written into the Bill at the last moment and only after vigorous, widespread objection to the earlier versions of the measure. One of the leading proponents of the Bill referred to the earlier version as an "easy firing bill"-which it was, for the accused employee could have been discharged if "on all the evidence there is a reasonable doubt concerning his loyalty," and there was no right to cross-examine witnesses or to an independent judicial review. Fortunately, this callous disregard of the legitimate interests of public employees was not shared by all proponents of the measure, and adequate procedural safeguards were finally incorporated in the Bill.

In the present temper of the times, it may be impolitic to question the soundness of the proposition that those who would overthrow the government should be discharged from its employ. Yet the proposition may not be axiomatic. Why should they be discharged? Is it because they should be punished by depriving them of this particular 
means of livelihood? If so, why not take the next step and prohibit their employment by private employers? Or why not impose penalties of fine and imprisonment? If the purpose of the discharge provisions is to punish those who entertain and advocate odious ideas, it conflicts with a basic tenet of democracy that thoughts are never to be controlled and words only in the extreme instance where uttering them creates a clear and present danger.

Or is the theory of the discharge provisions not punitive but preventive? Are "subversive" employees to be discharged because they constitute a potential fifth column or other threat to government stability or other social interest? There are government positions whose occupants should be above suspicion. Officials and employees in police departments or civil defense agencies, counter-espionage agents, and others in "sensitive" posts would by virtue of their positions be able to give valuable aid to a foreign enemy. But the garbage collector or the street cleaner of a municipality or an ordinary workman on a state road construction job does not by virtue of his position represent a danger to democratic institutions.

The Soviet Union and its agents in the United States are an undoubted threat to the security of the nation and to cherished democratic freedoms. Appropriate security measures should be adopted. But recognizing the magnitude and gravity of the Communist danger is only one side of the balance. On the other side are the values of freedom of expression, the very cornerstone of the democratic structure. In the words of Mr. John Lord O'Brian:

"The most important thing in all the world is the freedom of the individual. The advance of American civilization and its distinctive contribution to history are the results of the initiative, the intelligence, and the sense of moral values in the average citizen, which have found expression only through that freedom. Freedom of thought, freedom to express opinions, and in particular freedom to criticize are the phases most important to us, because they provide the warp and woof of our democratic social structure. . . .

"May it not well be that the greatest danger to our institutions lies not in threats of foreigners but in our own weakness in yielding to emotion and our increasing readiness to minimize and disregard the fundamental rights of the individual?" 23

23. O'Brian, New Encroachments on Individual Freedom, 66 HARv. L. Rev. 1-2, 26 (1952). Also to be weighed in the balance is the fact emphasized by Professor Zechariah Chafee that "Driving Communists out of their chosen occupations and putting a stigma on them which makes it almost impossible to obtain any other useful employment will not turn such persons into decent American citizens. Instead, they will be more embittered than ever, and they will have no means of keeping alive except to become agitators of a dangerous sort." CHAFEE, THIRTY-FIVE YEARS WITH FREEDOM OF SPEECH 15-16 (1952). 
The problem of subversion in public employment is real, complex and vital. Its solution calls for sustained thought and study, for a discriminating cataloguing of those positions of public employment whose sensitive character justifies special treatment, for a full appreciation of the fundamental values of free and open discussion, in short for a careful tailoring of means to ends and a balancing of security and individual freedom.

But this is not the approach of the Pennsylvania Loyalty Act, nor the solution it offers. The discharge provisions do not discriminate between sensitive and non-sensitive positions. Their adoption was not preceded by careful study and evaluation. The Act was designed by its principal draftsman to provide a basis for "easy firing" of public employees. Although incorporation of the procedural safeguards listed above frustrated the nefarious "easy firing" objective, the substantive restrictions which remain reflect the "easy firing" philosophy, at least insofar as they apply indiscriminately to all public employees.

There should be no underestimation of the difficulties of drafting and administering legislation which strikes a proper balance between security and individual freedom. It will not be easy to identify sensitive positions. People of ability and good will will differ as to where to draw the line. For example, the writer, at least, has found the problem of a Communist elementary or high school teacher particularly complex. On the one hand is the appealing reasoning of Alan Barth:

"The situation in public elementary and high schools may be said to differ somewhat from that in colleges and universities. A Communist teacher may exert a more baleful influence at the grade-school level; and any attempt to indoctrinate young pupils with alien propaganda-or any propaganda at all-should be strictly prohibited and vigorously counteracted. But tenure is important in the grade schools too. If teachers do their teaching competently-which means without propagandizing-it is safer to allow them political as well as religious vagaries than to undertake the dangerous course of judging them on the basis of imputed political beliefs. The excesses into which the latter undertaking inevitably leads are illustrated by the system of surveillance set up in the New York City public schools. There, school principals are required to report on the loyalty of the teachers under them, assistant superintendents on the loyalty of principals, and so on up to the apex of the city's Board of Education. The impact of such an arrangement on the morale of teachers, the atmosphere of general distrust bred by it, the possibilities of unjust accusations grounded in ignorance, bigotry, or malice, outweigh the danger that a few teachers may abuse the positions of trust they hold. It is surely preferable to confine punishment to actual, provable instances of abuse." 24

24. BARTE, op. cit. supra note 10, at 239. 
Against this counsel is the argument that it is exceedingly difficult to detect and prove "instances of abuse" and that no chances should be taken with the nation's most precious resource, the minds of its children. There may be a happy solution to this knotty question. If so, it has eluded the writer. All that can be said with confidence is that, despite the complexities of the task, the effort of reconciling security and freedom must be undertaken if basic civil liberties are to be protected.

\section{Applicants for Public Employment}

Section 4 of the Act provides that every "appointing authority shall establish, by rules, regulation, or otherwise, procedures designed to ascertain, before any person, including teachers and other employees of the public school system is appointed or employed, that he is not a subversive person and that there is no reasonable doubt on all the evidence as to the loyalty of the person involved to the government of the United States or the Commonwealth of Pennsylvania. In the event the applicant is deemed to be a subversive person, or in the event reasonable doubt as to loyalty exists, he shall not be appointed or employed."

Section 4 is gravely defective in at least two important respects. First, it directs appointing authorities to refuse to employ if there is "reasonable doubt as to loyalty." The appointing authority need not ascertain that the applicant is disloyal, but merely that there is reasonable doubt as to loyalty. Loyalty is not defined. ${ }^{25}$ Just what will this directive mean to the hundreds of appointing authorities throughout the Commonwealth? There is reason to be concerned that it may have about as many meanings as there are appointing authorities. For "loyalty" is an extremely elusive term. As former Attorney General Francis Biddle says, "A 'loyal American' does mean something very definite to each of us. Yet to each of us the meaning will be different." 26 The experience of the Federal loyalty program, which uses the same reasonable doubt of loyalty test, is not reassuring. Under that program loyalty often has been equated to conformity and orthodoxy,

25. Section $8(\mathrm{~b})$ of the Act provides as follows: "Activities and associations of an applicant which may be considered in connection with the determination of ineligibility [i.e., reasonable doubt of loyalty] may include, but shall not be limited to, one or more of the following: (1) Sabotage, espionage, or attempts or preparations therefor, or knowingly associating with spies or saboteurs. (2) Treason or sedition or advocacy thereof. (3) Advocacy of revolution or force or violence to alter the constitutional form of government of the United States or the Commonwealth of Pennsylvania. (4) Intentional unauthorized disclosure to any person under the circumstances which may indicate disloyalty to the United States or the Commonwealth of Pennsylvania, of documents or information of a confidential or non-public character, obtained by the person making the disclosure as a result of his employment by the Commonwealth of Pennsylvania or any political subdivision."

26. BiddLe, The FEar of Freedom 190 (1951). 
and there has been extensive use of the technique of guilt by association. $^{27}$

Second, section 4 provides for no procedural safeguards. Not only is there no right to a hearing on charges of subversion or disloyalty, but also there is nothing in section 4 which requires local appointing authorities who may doubt an applicant's loyalty to inform the applicant either in general or in detail that his loyalty is in question. An applicant for public employment thus may never know who accused him of subversion or disloyalty or whether the accusation resulted from malevolence, misinformation, or superpatriotism.

The total lack of procedural safeguards in section 4 coupled with the indefiniteness of the "reasonable doubt of loyalty" test means that the various appointing authorities have an almost unlimited discretion to refuse employment on loyalty grounds, and "loyalty" can mean practically whatever the particular appointing authority thinks it means. Thus the way is open for an investigation into an applicant's thoughts and ideas, and if he is found to be a nonconformist or a "radical" he need not be employed. The reader who thinks that this danger is remote or unreal should examine the working of the federal loyalty program. $^{28}$ Or consider the following excerpt from a letter dated August 12, 1951, written by a proponent of the Pechan Bill: "Canvas of loyal, American teachers show they are not opposed to this bill. Teachers who oppose the loyalty oath are those whom we do not want in our school system in the first place." 29 If the writer of that letter were an appointing authority or if an appointing authority shared the view expressed in the letter, is it not likely that opposition to loyalty legislation would become a basis for reasonable doubt of loyalty? And the action of the Loyalty Review Board of The Pennsylvania State College in the MacRae case recounted in the next section of this paper is an object lesson of what can happen to the independent nonconformist in a loyalty program.

It has not been possible to canvass all the appointing authorities throughout the Commonwealth to ascertain what procedures they have adopted to comply with section 4. A fairly wide sampling has, how-

27. See Emerson and Helfeld, Loyalty Among Government Employees, 58 YALE L.J. 1 (1948) ; BIDDLE, op. cit. supra note 26, at 197-245 ; BARTH, op. cit. supra note 10 , at 99 et seq.

28. See references in note 27 .

29. The letter was addressed "Dear Representative" and signed by "Louis Geo. Feldman," President of the Pennsylvania Joint Veterans Council. The entire letter was reproduced and given widespread publicity by the Citizens' Council on Democratic Rights. 
ever, been undertaken. ${ }^{30}$ The results of the survey are summarized in the following three paragraphs.

The Commonwealth and some larger political subdivisions have formulated fairly elaborate procedures. The applicant is required to fill in a "Loyalty Information" questionnaire, ${ }^{31}$ and his name is checked against the files of intelligence organizations. There appears to be no explicit provision in these procedures for informing the applicant of disqualifying information disclosed by the name check or other investigation, or for giving a suspected applicant an opportunity to explain or rebut the information or to cross-examine his accusers. Nor is there any indication that these appointing authorities have a clear or definite understanding of what is meant by "reasonable doubt of loyalty." There is in the Commonwealth a "Board of Review" which apparently handles all cases in which the application form or file check discloses derogatory information. Efforts to ascertain how the Board functions were not particularly rewarding. There was a marked reluctance on the part of the officials consulted to discuss the Board, its members, or its operation. One official who played a dominant role in passage of the Act and who is a member of the Board of Review stated that the existence and activity of the Board were "confidential matters." Why this should be so is not readily apparent. There can be no informed appraisal of the operation of section 4 procedures if the citizenry is

30. With the assistance of several students at the University of Pennsylvania Law School, information was secured concerning the procedures of approximately 40 appointing authorities. The writer is particularly indebted to Miss Melva L. Long and Messrs. Frederick T. Bebbington, John C. Bullit, William Fearen, and David $\mathrm{E}$. Wagoner. Their assistance should not be construed as an endorsement of the views expressed in the paper.

31. The questions asked in the City of Philadelphia Loyalty Information Questionnaire are as follows:

"1. Are you a citizen of or do you owe allegiance to the United States?

"2. Are you now, or have you ever been, a member of the Communist Party, U. S. A. or any Communist Organization?

"3. Are you now, or have you ever been, a member of a Fascist Organization?

"4. Are you now, or have you ever been, a member of any organization, association, movement, group, or combination of persons which advocates the overthrow of our constitutional form of government, or of an organization, association, movement, group, or combination of persons which has adopted a policy of advocating or approving the commission of acts of force or violence to deny other persons their rights under the Constitution of the United States or the Constitution of the Commonwealth of Pennsylvania or of seeking to alter the form of government of the United States or of the Commonwealth of Pennsylvania by unconstitutional means?

If your answer to question 2, 3 or 4 above is 'yes,' state in Item 5 the names of all such organizations, associations, movements, groups, or combinations of persons and dates of membership. Give complete details of your activities therein and make any explanation you desire regarding your membership or activities therein.

"5. Space for detailed answers to Questions 1, 2, 3, 4." 
deprived of the facts needed for intelligent evaluation. Invocation of the cloak of secrecy may give rise to a suspicion that there is something to hide.

Appointing authorities of smaller political subdivisions including school districts have in the main adopted less formal methods of complying with section 4. A few apparently proceed on the assumption that requiring the applicant to take a loyalty oath satisfies section 4 . Some require loyalty information on a form similar to that used by the larger political subdivisions, but do not check the applicant's name against intelligence files. Others rely on the usual investigation of the applicant's references and other traditional sources of information concerning his qualifications to bring to light evidence of subversion or disloyalty. Like the procedures adopted by the larger political subdivisions, the less formal procedures of the smaller political subdivisions contain no explicit procedural safeguards, and fail to define with any preciseness "reasonable doubt of loyalty."

Two appointing authorities indicated that applicants had been rejected because of reasonable doubt of loyalty; unfortunately, the officials supplying this information declined to describe the cases or to give examples of the type of information which led to disqualification.

It is apparent from this survey that the appointing authorities which have adopted procedures pursuant to section 4 have not remedied the two main defects of section 4 : the lack of procedural safeguards and the vagueness of the "reasonable doubt of loyalty" standard. At the very minimum, an applicant rejected because he is believed to be subversive or disloyal should be given an opportunity to explain or rebut the data on which the determination of subversion or disloyalty was made, and, wherever possible, he should be accorded the right to crossexamine his accusers. The inevitable vagueness of the reasonable doubt of loyalty standard is a compelling argument for its complete abandonment. Here, as in the case of the discharge provisions, there is need for a careful balancing of security and individual freedom, for patient, unspectacular pursuit of facts and the preparation of remedial measures in light of the specific need disclosed.

\section{Procedures of State-Aided Educational Institutions}

Section 13 of the Pennsylvania Loyalty Act prohibits payment of public funds "to any State-Aided institution of learning not a part of the public school system" 32 which fails to file with the Governor "a

32. The four principal state-aided educational institutions are the Pennsylvania State College, Temple University, University of Pennsylvania, and University of Pittsburgh. Athough there are other institutions of learning which receive state aid and thus are subject to section 13, time and space limitations have made it necessary to limit this section of the paper to the four named institutions. 
written report setting forth what procedures the institution has adopted to determine whether it has reason to believe that any subversive persons are in its employ and what steps, if any, have been or are being taken to terminate such employment. The report shall also unequivocally set forth that the institution has no reason to believe any subversive persons are in its employ." The report must be approved by the Governor before public funds can be paid.

The version of the Act originally passed by the Senate on March 28 required a loyalty oath not only from employees of the Commonwealth or of any of its political subdivisions but as well from employees of "any college or school which receives state aid." In April, 1951, representatives of the four principal state-aided educational institutions met in Harrisburg with legislators interested in loyalty legislation. The educational leaders emphasized the objectionable features of the oath requirement contained in the Bill the Senate had passed. They pointed to the experience of the University of California as an example of the harm that can result from ill-advised loyalty oath requirements. They urged that the objective of keeping subversives out of their institutions could better be achieved by delegating the task to the institutions-as had been done in Maryland by the Ober law-than by the blanket oath requirement of the Bill passed by the Senate. When the House Committee on State Government, to which the Senate Bill had been referred, reported the Bill out in May, the requirement of an oath from employees from state-aided educational institutions had been deleted and present section 13 had been incorporated. Although the version of the Bill reported out by the House Committee was drastically amended before its final enactment in December, 1951, section 13 went through that amendment process substantially unchanged.

The procedure adopted by Temple University, the University of Pennsylvania, and the University of Pittsburgh, pursuant to section 13 is one of certification. Although there are variations in the procedure of each of the institutions, the common element and distinctive feature is that supervising officials of the institution certify to the President of the institution that there is no reason to believe that persons under their supervision are subversive persons as defined in the Act. Relying on these certificates from officials who have knowledge of the persons concerning whom they certify and on his own knowledge of the certifying officials, the President can then unequivocally state to the Governor that the institution has no reason to believe that any subversive persons are in its employ.

The certification procedure is a sensible method of complying with the Act and at the same time not infringing academic freedom. It is 
clear from the legislative history of section 13 sketched above that the Act does not contemplate that state-aided institutions will require loyalty oaths of their employees. Avoidance of the furor and harm that such a requirement would cause was the purpose of amending the Bill after the April discussions in Harrisburg. For the same reason, it is apparent that the section does not contemplate that an institution need adopt procedures which, while not specifically requiring an oath, might be as offensive to reasonable faculty sensibilities as an oath requirement. Thus, the section does not require an institution to insist upon employees' filling out questionnaires or filing statements that are in substance as objectionable as the oath requirement of the Bill passed by the Senate in March.

Considerations such as these probably explain why Pennsylvania, Pittsburgh, and Temple utilized the certification procedure described above. But at the Pennsylvania State College these considerations apparently either were not advanced or were thought to be of insufficient weight. For at the College, although a certification procedure was utilized, the certifying official could not certify on the basis of his own knowledge of persons under his supervision. Instead, the certifying official could "use the most appropriate of three methods of ascertaining whether there is reason to believe that any of the persons under his jurisdiction is a subversive person within the meaning of the Pennsylvania Loyalty Act. If no evidence to the contrary appears, a certificate of loyalty is proper with respect to any person if:

"(a) He now has security clearance by the Federal Government or any of its subdivisions for the handling of classified information or in connection with government service.

"(b) He has taken the loyalty oath required by Federal or State employees. The oath is required only of those employees of this College who hold special Federal-College or Commonwealth-College appointments; failure to request or to execute such an oath or affirmation by others is not evidence of disloyalty; however, persons shall not be denied the right to make oath or affirmation of loyalty to the Commonwealth and Nation if they specifically and voluntarily request that right.

“(c) He satisfactorily completes the questionnaire designed by the College specifically to give assurance that he is not a subversive person as defined in the Pennsylvania Loyalty Act." 33

In the event that the normal administrative procedures did not "provide adequate certification concerning the loyalty of any employee of the

33. "Statement of Special Procedures used by The Pennsylvania State College in Complying with Section 13 of the Pennsylvania Loyalty Act of 1952." 
College . . . the name of that employee shall be referred to a Loyalty Review Board which shall make a thorough investigation after which the Board shall certify to the President of the College either (a) that to the best of its knowledge and belief the employee in question is not subversive as defined in the Loyalty Act, or (b) that a fair preponderance of the evidence shows the individual to be a subversive person." 34 If the uncertified employee so requested, he was to be granted a hearing before the Loyalty Review Board of the College. If the Board decided "that a fair preponderance of the evidence shows the uncertified individual to be a subversive person, he (or she) shall be dismissed within sixty (60) days notice of dismissal." The decision of the Loyalty Review Board was "final."

The questionnaire designed by the College specifically to give assurance that an employee was not a subversive person was titled "Personal Statement Made to Comply with the Provisions of the Pennsylvania Loyalty Act." After setting forth a summary of section 13 and quoting that statutory definition of "subversive person" and "subversive organization," the questionnaire read as follows:

"In order that the College can comply with the terms of the Loyalty Act it is necessary to request that you answer the following questions to the best of your ability.

1. Do you advocate the overthrow of our constitutional form of either State or Federal government by force or violence?

2. Are you knowingly a member of any political party or any club, society or organization which advocates the overthrow of our constitutional form of either State or Federal government by force or violence?

If 'yes,' please explain.

3. To the best of your knowledge and belief, can the President of the College certify unequivocally to the Governor and to the General Assembly of the Commonwealth that you are not now and will not knowingly become a subversive person as the term is defined in the Pennsylvania Loyalty Act and reproduced in the third paragraph of this statement? If 'no' please explain."

Such a questionnaire was presented to Mr. Wendell Scott MacRae, Publications Production Manager in the Department of Public Informa-

34. Italics supplied. "Composition of, and Procedures Followed by the Loyalty Review Board of the Pennsylvania State College," issued by "The President's Office" and dated May 10, 1952. Both this document and the "Statement of Special Procedures," supra note 33 , reflect a possible misunderstanding of the requirements of section 13 in that both refer to certification of the "loyalty" of an employee. Section 13 speaks only of a "subversive person" which is expressly defined in the Act, see note 18 supra. This confusion of a "loyal" person and a "subversive" person perhaps is not substantively significant. But it may be an indication that the College's analysis of section 13 was not as discerning as might be wished. 
tion at the Pennsylvania State College. On May 23, Mr. MacRae wrote to his superior, Mr. Louis H. Bell, Director of Public Information as follows:

"It is an American tradition and a Pennsylvania tradition as well, to resist oppressive and tyrannical legislation. The founders of this republic resisted such legislation and established a new and better government by the use of force and violence. Tagged as subversive by officials of the British Crown, they risked the hangman's noose to bring forth a new nation that has been a pattern for many others subsequently established.

"As a native-born beneficiary of the freedom thus secured by revolutionaries, I feel obligated to resist any un-American legislation such as the Pennsylvania Loyalty Act which on the pretense of bolstering national security encroaches on fundamental liberties. I am, therefore, returning to you uncompleted and unsigned the loyalty oath form and the questionnaire form tendered to me yesterday. I respectfully decline to take a political oath or to answer questions that are essentially political, as conditions of holding a job with The Pennsylvania State College. To fail to resist such effort at thought control is to court further and worse legislative encroachments on intellectual freedom.

"The president of the College already has vouched for me together with the entire faculty and staff in a press release defending the College against the scurrilous attacks of publicity-seeking patrioteers. I know no valid reason why he should not do so again. I suggest that my three-year record as an employee of the College and as a member of this community is a proper and far better guide to an appraisal of me as an American citizen than any tongue-in-cheek answers I might make to an absurd and insulting questionnaire." 35

In a letter dated June 25, 1952, the Chairman of the Loyalty Review Board, Mr. A. O. Morse, notified Mr. MacRae that the Board had been informed that the "normal administrative procedures of the College have not provided adequate certification concerning your loyalty. . . . It is our understanding that you have refused to fill out the statement drawn up by the College to comply with those sections of the Act which are applicable to state-aided institutions of learning." The letter also informed Mr. MacRae that he might request a hearing before the Loyalty Review Board, and it stated that "following the hearing, the Board shall inform the uncertified person of its findings within thirty days. If available evidence is inadequate for Board certification of the person's loyalty, the uncertified individual shall be dis-

35. Transcript of Proceedings before the Loyalty Review Board of The Pennsylvania State College in re: Wendell S. MacRae, August 26, 1952, pp. 8-9. (The page reference is to the single-spaced copy of the transcript; the original transcript was double-spaced). 
missed with sixty (60) days notice of dismissal." 36 Mr. MacRae requested a public hearing by letter dated July 26.

The hearing was held on August 26, 1952. The Loyalty Review Board was represented by counsel for the College, Roy Wilkinson, Esquire, who asked Mr. MacRae, "Have you ever advocated the overthrow of our constitutional form of either State or Federal Government, by force or violence?" Mr. MacRae answered, "I decline to answer that question. I have declined previously, and that's the reason I am here tonight, because I declined to answer those questions. I was informed by the Board that on account of declining to answer those questions I had to come here tonight and present evidence." Asked whether he refused "to answer any questions relating to the inquiry provided in Section 13 of the Loyalty Act of Pennsylvania," Mr. MacRae replied, "I decline to answer the questions I declined to answer before." Mr. Wilkinson then introduced into the record the exchange of correspondence between the Chairman of the Board and Mr. MacRae, and the letter written by the latter to Mr. Louis $\mathrm{H}$. Bell.

Mr. MacRae was not accompanied by counsel. He apparently had not anticipated that the Board would be represented by counsel, for early in the hearing he objected to "the formal procedure of which I was not notified." After Mr. Wilkinson had completed his questioning and had introduced the various letters into the record, Mr. MacRae made an oral statement to the Board. He urged that "the College in its choice of a method to implement the Pennsylvania Loyalty Act" had "gone beyond the authority delegated by the Act," that an employee could be dismissed under the Act only if he were found to be a subversive person, and that if the Board should order his dismissal "without a preponderance of . . . evidence" that he was a subversive person "it would be creating a situation of actionable libel in which the members of the Board would be personally liable." Mr. MacRae then stated that, although he was not required to do so, he would, in order to assist the Board to perform its "distasteful responsibility," demonstrate his "loyalty to our country."

Mr. MacRae's demonstration of "loyalty to our country" took the form of a sworn written statement. The statement began:

"In the matter of loyalty, I contend that the only way to judge the loyalty of a man to his country is by the pattern of his life-not

36. Transcript sitpra note 35 at 6 . Note the reference to "loyalty." Note also that under this procedure if "available evidence is inadequate" the employee shall be discharged, whereas under the regulations issued on May 10, the duty of the Board of Review was to decide "to the best of its knowledge and belief" either that the "employee in question is not subversive" or that the "Fair preponderance of the evidence shows the uncertified person to be a subversive person. . . ." See text at note 34 supra. This change in burden of proof is discussed infra pp. 25-26. 
by statements made under economic pressure. I shall of my own free will demonstrate to you, the members of the Loyalty Review Board of The Pennsylvania State College, that I am loyal to my country by giving you herewith a list of all the non-commercial organizations in which $I$ have held membership during my entire life. This list is a short one but complete to the best of my recollection. It indicates the pattern of my life in regard to religious, cultural, educational, political, military and social activities."

There were twenty-eight organizations listed, including the Presbyterian Church, St. Paul YMCA, American Red Cross, American Legion, and the United States Marine Corps. The statement also set forth, "to the best of my recollection," the oath Mr. MacRae took when he received his Marine Corps commission:

"I, Wendell MacRae, do solemnly swear that I will support and defend the Constitution of the United States against all enemies, foreign and domestic; that I take this oath of my own free will without any mental reservation or purpose of evasion, so help me God."

Mr. MacRae stated that he considered "this oath as binding upon me today as on the day it was administered to me. In taking a stand for Constitutional law here tonight, I feel that I am fulfilling an obligation under that oath."

Mr. MacRae also called two witnesses on his behalf: his neighbor, Mr. Victor Held, and his supervisor, Mr. Louis H. Bell, Director of the Department of Public Information at the College. Mr. Held testified, "I have absolutely no grounds to consider you subversive." Mr. Bell stated that he had been willing to certify Mr. MacRae to the President and that he was still willing to certify him to the Board. ${ }^{37}$ Mr. MacRae then asked Mr. Bell whether his services in the Department of Public Information had been satisfactory. Mr. Wilkinson objected to the question "as not being relevant. We are not inquiring into your satisfactory record." The objection was sustained. Except for this objection, neither Mr. Wilkinson nor any member of the Board challenged any of Mr. MacRae's evidence.

37. On this point, the transcript, supra note 35 , at p. 16 , reads as follows:

"Mr. MacRaE: Mr. Bell, I would like to have you tell the Board, if you will, please, that you were willing to certify me before any of this came up, when I declined to sign the Loyalty Oath and answer the questionnaire, and that you are still willing to certify me to the Board.

"Mr. BerI: That is correct. I think there are many people in my position on the Campus who know of the people sufficiently well to certify them if they could, and I would pe very much surprised if you turned out to be a subversive.

"Mr. MacRas: Aren't you convinced yet?

"Mr. BELL: My answer to that is, the only thing you can be sure of is that you can't be sure of anything, and that is not original." 
The next morning the Chairman of the Board wrote Mr. MacRae, "You are hereby advised that the Loyalty Review Board of The Pennsylvania State College finds that it lacks sufficient evidence essential to certify to the President of The Pennsylvania State College that you are not subversive as the term 'subversive' is defined in the Pennsylvania Loyalty Act." Mr. MacRae immediately wrote to Milton S. Eisenhowever, President of the College, protesting the action of the Board and requesting the President to review the action of the Board, and "to certify me to the Governor." The President replied on August 28: "The Loyalty Review Board has informed me that it lacks sufficient evidence essential to certify to me that you are not subversive as the term 'subversive' is defined in the Pennsylvania Loyalty Act. This being the case, I have no alternative but to discharge you immediately as an employee of The Pennsylvania State College." 38

Early in September, a special Committee representing members of the faculty and employees of the College and interested citizens of the community was formed to urge President Eisenhower to (1) revise the procedures adopted by the College, (2) affirm the principle that a hearing before the Loyalty Review Board is an alternative method of certifying a College employee, and (3) reopen the MacRae case. ${ }^{39}$ The Committee met with President Eisenhower. Late in September President Eisenhower authorized the creation of a seven-man Committee of members of the faculty to review the procedures of the College adopted under section 13 and the application of the procedures to any particular case. This Committee submitted its recommendations in the middle of November. Important changes in procedures recommended by the Committee were: (1) New employees of the college must be certified; certification is proper if (a) the applicant has a security clearance by the federal government, or (b) has taken a loyalty oath, or (c) has satisfactorily completed the questionnaire designed by the College specifically to give assurance that he is not a subversive person. If, however, an applicant for employment feels that "Because of religious or other conscientious objections, he cannot comply with the above methods of certification, the certifying officer may . . . certify such applicant on the basis of an investigation, but in this event the responsibility shall rest upon the applicant to furnish the certifying officer with

38. The letter closed with the statement, "Enclosed herewith is a check covering your salary for twenty-eight days in August, plus sixty days' additional pay, which is in accordance with the College policy of giving sixty days' notice of dismissal."

39. The Committee consisted of Professors Elton Atwater, John H. Ferguson, Hans Neuberger, Joseph G. Rayback, and William L. Werner, Chairman. It was known as the MacRae Defense Committee. This Committee deserves the thanks and respect of all persons interested in civil liberties. All of its members, particularly its chairman, spent long hours on the case, and performed their difficult task with courage, moderation, and effectiveness. 
such information or references as may be essential for certification. In certifying any such person to the President . . . the certifying officer shall accompany such certification with a summary of his investigation." (2) In the event of a hearing before the Loyalty Review Board, "No employee of the College shall be found by the Board to be a subversive person . . . except by the fair preponderance of the evidence." (3) The President shall sustain or reverse the Board's decision, and the President's decision shall be final. ${ }^{40}$

Part II of the Committee's report dealt with the MacRae case. ${ }^{41}$ The Committee recommended that "should Mr. MacRae elect to do so, he be permitted to apply for re-employment with the College, subject to the regulations which will apply in the future to all candidates for employment" as recommended in the first part of the report. It was later agreed by the Committee, the Faculty Advisory Council and the college administration that Earl G. Harrison, Esquire, member of the Philadelphia Bar and former Dean of the University of Pennsylvania Law School, should act as the certifying officer in the event that Mr. MacRae applied for re-employment.

Mr. MacRae did so apply. Mr. Harrison conducted his investigation and submitted his report to President Eisenhower. In the report, Mr. Harrison stated, "I unqualifiedly certify that Wendell Scott MacRae is not a subversive person, as that term is defined in the Pennsylvania Loyalty Act or under any other reasonable definition." ${ }^{42}$ On December 6, Mr. MacRae was reinstated in his former position.

So ends the case of Wendell S. MacRae. It has been told in such detail because it depicts loyalty programs in action, although here the final disposition was more propitious than in most cases. Almost invariably the person hurt by a loyalty program is not the disloyal or the subversive, but the idealist and the nonconformist. In this instance it was Mr. MacRae, age 52, the father of two dependent children, who was discharged from his job. ${ }^{43}$ He found himself in that unfortunate

40. Reports from the College indicate that the substance of these recommendations will be adopted.

41. There are several portions of this section of the Committee's report with which the writer disagrees; see particularly note 44 infra. But it is not likely that any useful purpose would be served by elaborating the points of disagreement in this paper.

42. Report of Ear1 G. Harrison to The Pennsylvania State College 14 (Nov. 22, 1952). Mr. Harrison performed a valuable public service in undertaking the thankless task of acting as certifying officer in this case. The writer concurs in Mr. Harrison's conclusion that Mr. MacRae is not a subversive person; there are however certain portions of the Harrison report with which he would take issue.

43. Not only did Mr. MacRae lose approximately $\$ 600$ in salary, but he, his wife, and two children, aged 14 and 5 , went through the disconcerting experience of being without a means of livelihood and of having him stamped as a person as to whom there was not sufficient evidence to be declared non-subversive. The defense group contributed approximately one-fourth of the $\$ 600$ salary loss to the MacRae family for living expenses, and present plans call for raising the other three-fourths in the event the College does not fully reimburse Mr. MacRae for his loss of salary. 
position because of two circumstances, neither of which in any way reflected on his "loyalty" or devotion to the government of the United States or of the Commonwealth of Pennsylvania. The first circumstance was that he is one of those rare individuals who acts according to his convictions. He believed the Pennsylvania Loyalty Act "encroaches on fundamental liberties." Therefore he would not take the oath or fill in the questionnaire. Mr. MacRae might have been unwise in his actions. Perhaps in a democracy one should accept the decision of the majority even if deeply held convictions are at stake. But whether he was an unwise dissident, on the one hand, or a brave defender of freedom, on the other, is quite beside the point. For in neither case was there any reason to believe that he was subversive. Miss Vivian Kellems has refused to deduct the federal withholding tax from the wages of her employees. Miss Kellems may be unwise, or a fighter for freedom, depending on the view of the person appraising her actions. But her resistance to the law is no evidence that she is subversive. No more did Mr. MacRae's resistance to the College's "loyalty" requirements tend to indicate that he was subversive.

The second circumstance which caused Mr. MacRae's unhappy situation was the failure of the tribunal which heard his case to appraise the evidence properly. The writer has carefully studied the transcript of the hearing before the Board. On the basis of the evidence there adduced there is no question in the writer's mind that Mr. MacRae's refusal to answer the questions put to him by counsel for the Board, like his refusal to sign the oath or complete the questionnaire, was due to principle and not evasion. The hearing tribunal unquestionably should have found that Mr. MacRae was not subversive. ${ }^{44}$

It is not easy to understand why the Board failed to make that finding. The most likely explanation is that the members of the Board, who were not lawyers, misunderstood the provisions of the regulations governing the procedures and responsibilities of the Board. As originally issued on May 10, 1952, the Board was to "make a thorough investigation after which the Board shall certify to the President of the College either (a) that to the best of its knowledge and belief the employee is not subversive as defined in the Loyalty Act, or (b) that a fair preponderance of the evidence shows the individual to be a subversive person." 45 On June 30 this provision of the regulation was

44. In fairness to the Board it should be reported that the 7-man Committee and Mr. Harrison both concluded that the Board acted correctly in concluding that it did not have sufficient evidence to decide that "to the best of its knowledge and belief the employee in question is not subversive."

45. It is to be noted that the Board failed to make the "thorough" investigation required by the regulations. 
changed to require the Board to "make a thorough investigation, after which the Board shall certify to the President of the College either (a) that to the best of its knowledge and belief the employee in question is not subversive as the term 'subversive' is defined in the Loyalty Act, or (b) that the Board lacks evidence essential for such certification." 46 This thoroughly undesirable change in procedure was not required by section 13 of the Act. Apparently the Board felt that, because Mr. MacRae refused to answer the questions put to him by counsel for the Board, it lacked evidence to conclude that "to the best of its knowledge and belief" Mr. MacRae was not subversive. The position of the Board thus appears to have been that, although a hearing was provided in the event that an employee refused to take the oath or answer the questionnaire, the only way a person could get clearance from the Board would be to answer the questionnaire at the hearing. Such an interpretation would render the opportunity of a hearing meaningless for an employee who for reasons of conscience declined to take the oath or answer the questionnaire.

It is possible that the Board felt that Mr. MacRae should have adduced additional evidence of his lack of subversive characteristics by securing affidavits from other associates and neighbors, from former employers, and perhaps by asking for an FBI or other file check. But it must be remembered that he was not represented by counsel at the hearing and that he understood the hearing would be informal. In light of these facts, his notarized statement of organizational affiliations and re-affirmation of his Marine oath certainly provided adequate basis for "knowledge and belief" that he was not subversive. It should be remembered also that section 13 of the Loyalty Act does not require a finding that a person is not subversive but simply that "the institution has no reason to believe that any subversive persons are in its employ." In the absence of any evidence that Mr. MacRae advocated the forcible overthrow of the government or knowingly belonged to an organization advocating such overthrow or any other evidence that he was subversive, there was ample information in the record at the hearing to conclude that the institution had no reason to believe that Mr. MacRae was subversive.

Mr. MacRae has been reinstated. But section 13 remains. So long as administrative and certifying officials act with courage and

46. There was an unexplainable delay in distributing the changed regulations to the staff and the faculty. According to the MacRae Defense Committee's explanatory letters to the faculty: "No effort was made to call the attention of the faculty or staff to the specific change which the June version made. Even at the time of the hearing, most of those present were not aware of the change until mention was made of it in the testimony, and the reaction was one of complete surprise." Italics in text supplied. 
moderation and political leaders of the Commonwealth do not seek to utilize section 13 to impose their own standards of loyalty on educational institutions, section 13 should not infringe academic freedom. But its existence represents a threat to educational freedom and independence in the Commonwealth. It will discourage some scholars from joining Pennsylvania educational institutions, ${ }^{47}$ and there is no assurance that college administrators will always be courageous or that petty politicians will not seek to impose their will on the institutions. To paraphrase the words of a commentator on the Maryland Ober Act: In the writer's opinion the present political leaders of the Commonwealth have too much respect for the great educational institutions of Pennsylvania to seek to put them under any sort of political control. It may not always be thus. ${ }^{48}$

\section{Conclusion}

A basic criticism of the Pennsylvania Loyalty Act and the manner of its enactment is that there was and has been no demonstration of need for the various provisions of the law. The history of oath provisions in other states and municipalities has shown that oath laws usually have punished not Communists but Quakers and other idealists and nonconformists. Cogent reasons for barring subversives from the ballot were never advanced. New legislation for discharging Communists and other subversives from the school system and other public employment was unnecessary, because prior to the Act there were ample statutory provisions for discharging persons who advocated or participated in "un-American or subversive doctrines." 49 The fact that

47. One such instance has occurred at the Pennsylvania State College. Jon Swan, son of a Presbyterian clergyman (as is Mr. MacRae), turned down a post as graduate assistant in the English Department because of "conscientious objections" to the College's "loyalty" procedures. His statement as reported in the Centre Daily Times, September 11, 1952, reads in part as follows:

"I believe we shall not experience loyalty through uniformity, through signing papers, taking oaths.

When a university has lost its clear appraisal of a man's worth and testimony, or has lost its confidence in the fullness of truth and in training to judge, consider, and out of a number of varied approaches, conclude for himself what is clearest, most fitting-then the university has lost in the deepest sense its liberal art.

"Is it to such an institution where men and women are signed to a silly and useless statement where their intellects are hunched under the stature of the Pechan bill-that a man or woman will come for the development of his or her clear thought? Educators may find the time near and necessary to show misled and harried politicians that if laws can be made without thought, thinkers will strike for their freedom."

48. Prendergast, supra note 7 , at 180 .

49. PA. Stat. ANN. tit. 24, $\$ 1122$ (Purdon 1950) provided that valid causes for termination of a teacher's contract included "advocation of or participating in unAmerican or subversive doctrines. . .." Pittsburgh school teacher Miss Dorothy Albert was discharged under this statute. See In re Appeal Dorothy Albert, 127 The Legal Intelligencer No. 102, p. 1 (Phila. Nov. 26, 1952). The Act of July 28, 1941, P.L. 214 provided that any employee of the Commonwealth or its political subdivisions who "advocates or participates by an overt act or acts in un-American 
after the Act has been passed most appointing authorities apparently continue to rely on traditional sources of information concerning applicants for public employment suggests that there was little need for special legislation on that subject. Trustees, administrators, and faculties of state-aided educational institutions had not been derelict in maintaining proper educational standards, nor had evidence been advanced that those institutions were infested with Communists or other subversives. Instead of coming to grips with the problem of Communism, of ascertaining why misguided Americans become Communists, and of trying to reclaim them to democracy's ranks, the Act represents a surrender to the not uncommon weakness of "enacting a law"-a law which purportedly meets a need, but which in fact does little, if anything, to remedy the underlying evil.

Why, then, did men of ability and good will propose, and other similar persons enact, the law which contributes little or nothing to security, harms innocent persons of conscience, and creates an atmosphere of resentment, fear, and mistrust? The answer is at least threefold. First, there was a faulty estimate of the problem of subversion and the available means of meeting the evil. Instead of ascertaining whether there were Communists or other subversive persons in public employment, this fact was assumed. Instead of examining existing laws to determine whether they were adequate to protect the public interest, scissors and paste were employed to copy sections of the Federal loyalty program and the Maryland Ober law. Second, Americans understandably detest the dictatorial and brutal methods of Communism. This feeling of revulsion and hate provokes the reaction that something must be done to protect our own democratic rights. Persons in that frame of mind are apt to act on the basis of emotion rather than reason. And the result is likely to be, once more, "to enact a law" to demonstrate our hatred of Communism. Third, laws are passed by the people's elected representatives, and voting against "loyalty". legislation can be misrepresented by one's opponent. As Senator John H. Dent, Minority Leader, stated in the debate on the Pechan Bill:

"Mr. President, I would be derelict in my duties to the Democratic Party if I did not vote for this piece of legislation today. I agree in principle and in fact with statements . . . [of opponents of the bill]. This legislation should not be before us today. . . Mr. President, I cannot permit my party to be

or subversive doctrines" shall be dismissed. It is true that this statute called for proof of an "overt act or acts," and thus might not permit discharge of someone who merely advocated overthrow of the government. It is not likely, however, that any dangerous subversive would not commit some overt act within the meaning of the statute. See also Pawell v. Unemployment Compensation Board of Review, $146 \mathrm{~Pa}$. Super. 147, 22 A.2d 43 (1941). The two statutes cited in this footnote were repealed by section 16 of the Pennsylvania Loyalty Act. 
further stigmatized as a party friendly to un-American activities. . . . [M] y vote in 1945 . . . [against "removing the communists from the ballot by legislative act"] was vindicated, because it was declared unconstitutional, but all the newspapers and the people in my community, who felt that they were doing what they thought was right, burned me in effigy upon my front lawn and, although I was characterized as a Red and a near Red or a 'pink,' or whatever you want to call it, there was never an apology made to my family, there was never a word of retraction made after the bill was declared unconstitutional. So, Mr. President, in the face of that injustice, in fairness to my family, I will vote for this legislation. . . . We are living in a day when men will hide behind the decent emblem of patriotism to do things that they would not do openly, but as a leader of my party I must subscribe to the days that we live in. . . . Mr. President, I will vote for this measure because the injustices of the day demand me to vote for it." 50

The central issue of our times is the maintenance of national security and the preservation of individual freedom. It is the task of statesmanship to harmonize these two basic democratic interests. It is the responsibility of citizenship to appraise the statesmen's striking of the balance. Legitimate security measures should be enthusiastically supported. But before individual freedom is sacrificed, care must be taken that a security need actually exists, that the measure has a realistic relation to the ascertained security objective, and that there are not other and better means to meet the need.

Communism is a sinister danger to democracy. We are engaged in a grim struggle with that form of totalitarianism both on the field of battle and in the realm of ideas. But it will profit us little to strike blindly at a large group of loyal citizens in the wild chance or hope that an enemy will be found. To do this is not to develop loyalty but to promote fear and suspicion. The likely consequence of legislation of this character is repression of loyal Americans rather than detection and punishment of dangerous subversives. And to repress and intimidate our own citizens is to court disaster. In the striking words of America's greatest living jurist, Learned Hand, the "community is already in the process of dissolution where each man begins to eye his neighbor as a possible enemy, where nonconformity with the accepted creed, political as well as religious, is a mark of disaffection; where denunciation without specification or backing takes the place of evidence; where orthodoxy chokes freedom of dissent; where faith in the eventual supremacy of reason has become so timid that we dare not enter our convictions in the open lists to win or lose." 51

50. 1 Pennsylvania Legislative Journal 1050-1051 (1951).

51. Address at the 86th Convocation of the University of the State of New York, delivered Oct. 24, 1952, at Albany. N.Y. Times, Oct. 25, 1952, p. 1, col. 1. 